\title{
OPTIMASI PENGGUNAAN WAKTU PEMBERSIHAN UNTUK SUKSESI TRANSPLANTASI KARANG ACROPORA MILLEPORA DI PERAIRAN MALANG RAPAT, BINTAN
}

\section{OPTIMIZATION OF USE OF CLEANING TIME FOR SUCCESSION TRANSPLANTATION OF CORAL ACROPORA MILLEPORA IN MALANG RAPAT WATERS, BINTAN}

\author{
Bukhari $^{1}$, Risandi Dwirama Putra² \& Dedy Kurniawan ${ }^{3}$ \\ ${ }^{1}$ Jurusan Ilmu Kelautan, Fakultas Ilmu Kelautan dan Perikanan, Universitas Maritim Raja Ali Haji \\ ${ }^{2}$ Jurusan Teknik Perkapalan, Fakultas Teknik, Universitas Maritim Raja Ali Haji \\ ${ }^{3}$ Jurusan Manajemen Sumberdaya Perairan, Fakultas Ilmu Kelautan dan Perikanan, Universitas Maritim Raja Ali Haji \\ Jln. Politeknik, Senggarang, Kota Tanjungpinang \\ e-mail : dedykurniawan@umrah.ac.id
}

Diterima tanggal: 10 Februari 2020 ; diterima setelah perbaikan: 05 September 20217 ; Disetujui tanggal: 06 September 2021

\begin{abstract}
ABSTRAK
Tujuan penelitian ini adalah mengetahui pertumbuhan, tingkat kelangsungan hidup dan mengetahui pengaruh frekuensi waktu pembersihan terhadap keberhasilan transplantasi karang keras (Acropora millepora) di Perairan Malang Rapat, Bintan. Penelitian ini dilakukan dengan metode transplantasi menggunakan modul terbuat dari semen berbentuk balok. Transplantasi karang dilakukan dengan empat perlakuan, perlakuan A (fragmen dibersihkan setiap 1 minggu), perlakuan B (fragmen dibersihkan setiap 2 minggu), perlakuan C (fragmen dibersihkan setiap 3 minggu) dan perlakuan D (tidak ada pembersihan fragmen) dengan 5 kali pengulangan setiap perlakuan. Pengamatan dilakukan setiap minggu selama 12 minggu penelitian. Hasil penelitian menunjukkan pertumbuhan mutlak pada perlakuan A sebesar 14,94 $\pm 4,98 \mathrm{~mm}$, perlakuan B sebesar 18,16 \pm $5,93 \mathrm{~mm}$, perlakuan $\mathrm{C}$ sebesar 12,30 $\pm 3,78 \mathrm{~mm}$ dan perlakuan D sebesar 12,22 \pm 4,34 $\mathrm{mm}$. Laju pertumbuhan fragmen karang pada perlakuan A sebesar 1,24 $\pm 0,41 \mathrm{~mm} /$ minggu, perlakuan B sebesar 1,51 $\pm 0,49 \mathrm{~mm} /$ minggu, perlakuan $\mathrm{C}$ sebesar 1,02 $\pm 0,31 \mathrm{~mm} / \mathrm{minggu}$, dan laju perlakuan $\mathrm{D}$ sebesar 1,01 $\pm 0,36 \mathrm{~mm} / \mathrm{minggu}$. Tingkat kelangsungan hidup fragmen karang Acropora millepora pada perlakuan A dan B sebesar 100\% (tidak mengalami kematian), sedangkan perlakuan C dan D sebesar 83,08\% (mengalami kematian). Hasil uji statistik menunjukkan terdapat perbedaan yang nyata antara pertumbuhan karang Acropora millepora berdasarkan perbedaan waktu pembersihan. Perlakuan B (pembersihan fragmen setiap 2 minggu sekali) merupakan perlakuan dengan pertumbuhan optimum.
\end{abstract}

Kata kunci: Transplantasi karang, Acropora millepora, pertumbuhan karang.

\section{ABSTRACT}

The purpose of this study was to determine growth, survival rates and determine the effect of the frequency of cleaning time on the success of hard coral transplantation (Acropora millepora) in Malang meeting waters, Bintan. This research was carried out by the transplantation method using modules made of cement in the form of blocks. Coral transplantation was carried out with four treatments, treatment A (fragments cleaned every 1 week), treatment $B$ (fragments cleaned every 2 weeks), treatment $C$ (fragments cleaned every 3 weeks) and treatment $D$ (without fragment cleaning) with 5 repetitions of each treatment. Observations were made every week for 12 weeks of research. The results showed absolute growth in treatment $A$ was $14.94 \pm 4.98 \mathrm{~mm}$, treatment $B$ was $18.16 \pm 5.93 \mathrm{~mm}$, treatment $C$ was $12.30 \pm 3.78 \mathrm{~mm}$ and treatment $D$ was $12.22 \pm 4.34 \mathrm{~mm}$. The growth rate of coral fragments in treatment $A$ was $1.24 \pm 0.41 \mathrm{~mm} /$ week, treatment $B$ was $1.51 \pm 0.49 \mathrm{~mm}$ / week, treatment $C$ was $1,02 \pm 0.31 \mathrm{~mm} /$ week, and treatment $D$ is $1.01 \pm 0.36 \mathrm{~mm} /$ week. The survival rate of Acropora millepora coral fragments in treatments $A$ and $B$ was $100 \%$ (no deaths), whereas treatments $C$ and $D$ were $83.08 \%$ (deaths). Statistical test results show that there is a significant difference between Acropora millepora coral growth based on differences in cleaning time. Treatment B (cleansing fragments every 2 weeks) is a treatment with optimal growth.

Keywords: coral transplantation, Acropora millepora, coral growth..

Optimasi Penggunaan Waktu Pembersihan untuk Suksesi Transplantasi Karang Acropora Millepora di Perairan Malang Rapat, Bintan - Bukhari, Risandi Dwirama Putra, \& Dedy Kurniawan 


\section{PENDAHULUAN}

Metode transplantasi karang merupakan cara sederhana untuk memperbaiki kondisi ekosistem terumbu karang yang rusak (Haris et al., 2011). Berbagai kalangan dapat terlibat dalam mengusahakan dan melakukan rehabilitasi karang dengan metode ini. Setiap tahap dalam pelaksanaan transplantasi karang merupakan faktor kunci dalam keberhasilan transplantasi karang (Subhan et al., 2014).

Salah satu permasalahan dalam kegiatan transplantasi terumbu karang yaitu pemilihan lokasi transplantasi (Kurniawan et al., 2017). Daerah yang dipilih untuk melakuan kegiatan transplantasi karang, pada umumnya hanya mempertimbangkan kondisi fisika dan kimia perairan. Selain kondisi fisika dan kimia perairan, kondisi tentang faktor biologi di lokasi transplantasi juga sangat dibutuhkan. Alga dan penyakit karang merupakan faktor yang perlu diperhatikan. Pemilihan lokasi yang minim terdapat makro alga sebagai prioritas untuk dalam kegiatan dalam transplantasi karang (Subhan et al., 2014).

Menurut Edwards \& Gomez (2008), dalam kegiatan transplantasi terumbu karang sangat wajar bila dilakukan perawatan rutin. Pemantauan sistematis dilakukan setiap beberapa bulan sekali, tetapi akan menguntungkan bila memeriksa transplantasi lebih sering dari gangguan pemangsaan dan pertumbuhan alga yang cepat atau alga yang menempel di karang. Perawatan rutin dapat berupa pembersihan area sekitar karang transplan dari alga. Alga-alga tersebut bila dibiarkan tumbuh akan mengganggu pertumbuhan karang transplan dan proses pelekatan karang transplan ke substrat (Putra et al., 2018)

Kabupaten Bintan khususnya di Perairan Malang Rapat merupakan tempat wisata yang luas sehingga pada kawasan ini banyak pengusaha hotel melakukan pembukaan lahan untuk pembangunan hotel dan tempat wisata umum lainnya yang kebanyakan berada pada daerah pantai yang akan menyebabkan terjadinya sedimentasi. Dean \& kleine (2011), menyatakan bahwa adanya sedimentasi yang tinggi di ekosistem terumbu karang dapat mempercepat pertumbuhan alga.

Perawatan dan pembersihan terhadap terumbu karang yang ditransplantasi perlu dilakukan untuk dapat meningkatkan pertumbuhan dan kelangsungan hidup karang transplantasi. Permasalahan mengenai perawatan dan pembersihan pada transplantasi terumbu karang belum pernah diteliti sebelumnya. Oleh karena itu, penelitian ini bertujuan untuk mengetahui pertumbuhan mutlak, laju pertumbuhan dan tingkat kelangsungan hidup, serta menganalisis pengaruh frekuensi waktu pembersihan terhadap laju pertumbuhan karang Acropora millepora yang ditransplantasi pada kondisi alami, yaitu di Perairan Malang Rapat, Bintan.

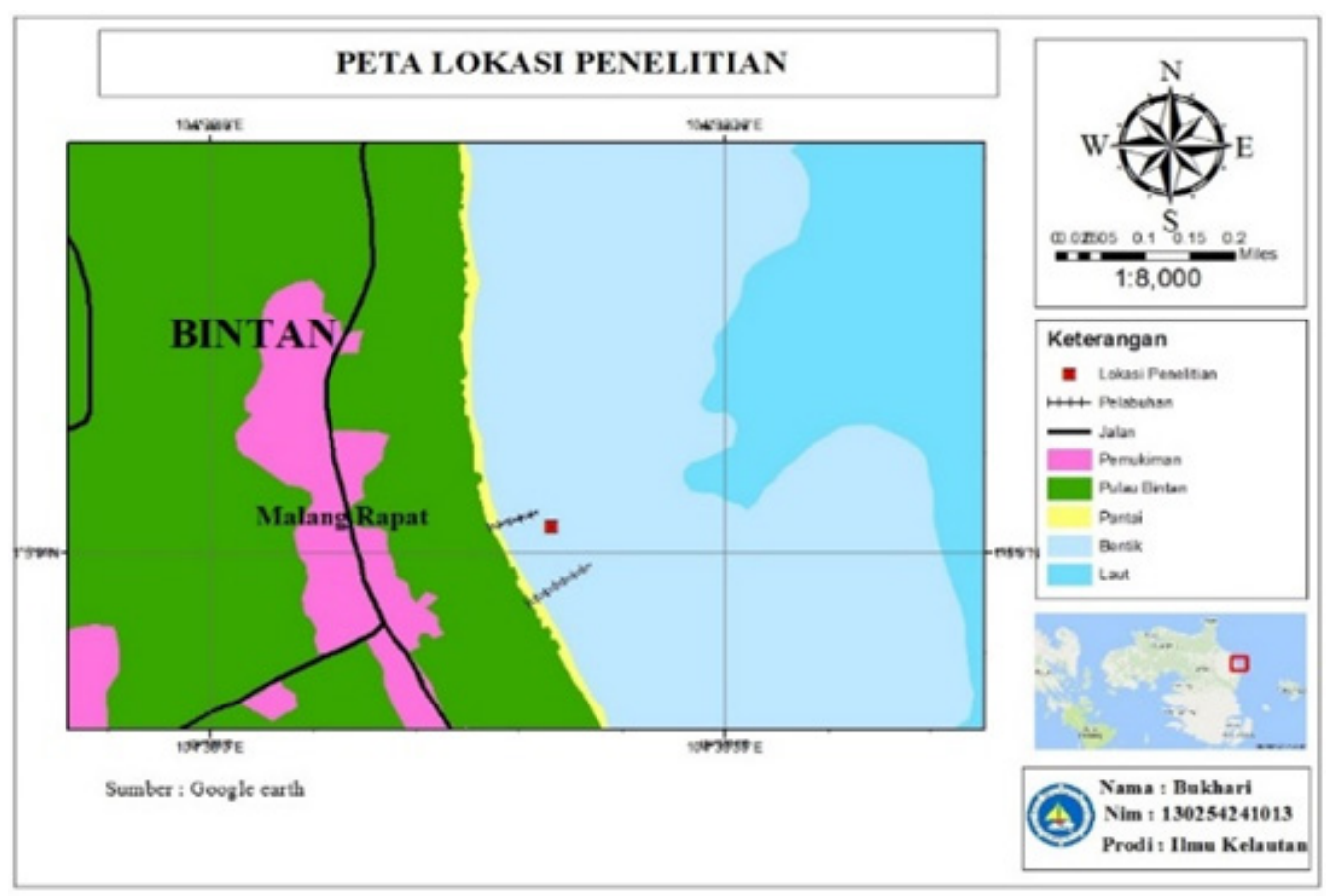

Gambar 1. Peta lokasi penelitian.

Figure 1. Map of research location. 


\section{BAHAN DAN METODE}

Penelitian dilaksanakan selama 6 bulan mulai awal Maret sampai akhir Agustus 2018. Penelitian dimulai dari pemilihan lokasi, persiapan substrat transplantasi, aklimatisasi substrat dan pengamatan pertumbuhan, serta tingkat kelangsungan hidup. Pengambilan data pertumbuhan karang transplan dilakukan selama 3 bulan (12 minggu) yang dimulai sejak karang ditransplantasi. Lokasi penelitian di Perairan Malang Rapat, Bintan. Stasiun penelitian terletak pada Koordinat $1^{\circ} 18^{\prime} 82^{\prime \prime}$ LS dan 104'34'43" BT. Peta lokasi penelitian dapat dilihat pada Gambar 1.

\section{Alat dan Bahan}

Alatdanyang digunakanuntukpenelitianinimeliputialat yang digunakan dalam pengamatan dan pengambilan data pertumbuhan karang serta pengamatan parameter lingkungan. Antara lain : peralatan selam (SCUBA), caliper, GPS, kamera bawah air, semen balok, fragmen karang A. millepora, lem epoxy, pensil, sabak, laptop, perahu, tang, adapun alat pengukur parameter perairan antara lain: handrefraktometer, Thermometer, DO meter, $\mathrm{pH}$ meter, patok skala, floating droudge, turbidity meter, sediment traps dan timbangan analitik.

\section{Prosedur Penelitian}

Rancangan penelitian transplantasi karang ini dilakukan dengan 4 perlakuan 5 pengulangan di lokasi yang sama. Karang yang digunakan dalam penelitian yaitu karang A. millepora. Modul terbuat dari semen berbentuk balok dengan panjang $1 \mathrm{~m}$, lebar $10 \mathrm{~cm}$ dan jumlah 4 batang, modul ini mengacu pada penelitian, (Irawan et al., 2019). Karang Acropora millepora dipotong sebanyak 20 fragmen karang dengan ukuran panjang $80 \mathrm{~mm}$ terbagi atas $60 \mathrm{~mm}$ untuk sampel dan $20 \mathrm{~mm}$ untuk proses penempelan. Mengacu pada pernyataan Edwards \& Gomez (2008), ukuran fragmen yang cukup baik, minimal 50-100 mm, untuk meningkatkan keberhasilan dan keragaman topografi. Setiap besi pada substrat semen yang telah dipasangkan, di bagian bawah ditempel dengan tumpukan lem epoxy dengan tinggi $20 \mathrm{~mm}$ yang sudah disediakan hingga menyatu bagian antara besi dan substrat. Karang ditempel ke lem dan diikat dengan kabel ties sehingga fragmen karang dalam posisi tegak lurus dan kokoh. Fragmen karang yang telah ditransplantasi pada substrat, dilakukan perlakuan yang secara rinci dapat dilihat dalam Tabel 1. Gambaran substrat desain dan peletakan perlakuan karang transplantasi dapat dilihat pada Gambar 2.

Tabel 1. Kode perlakuan

Table 1. Treatment codes

\begin{tabular}{lll}
\hline No & $\begin{array}{l}\text { Kode Sampel } \\
\text { Perlakuan }\end{array}$ & Keterangan \\
\hline 1 & A & Perlakuan fragmen karang dengan pembersihan selang waktu 1 minggu 1 kali dibersihkan \\
2 & B & Perlakuan fragmen karang dengan pembersihan selang waktu 2 minggu 1 kali dibersihkan \\
3 & C & Perlakuan fragmen karang dengan pembersihan selang waktu 3 minggu 1 kali dibersihkan \\
4 & D & Perlakuan fragmen karang dengan pembersihan selang waktu tidak sama sekali dibersihkan \\
& selama 3 bulan penelitian & Jumlah ulangan setiap perlakuan fragmen karang \\
5 & $1,2,3,4,5$ &
\end{tabular}
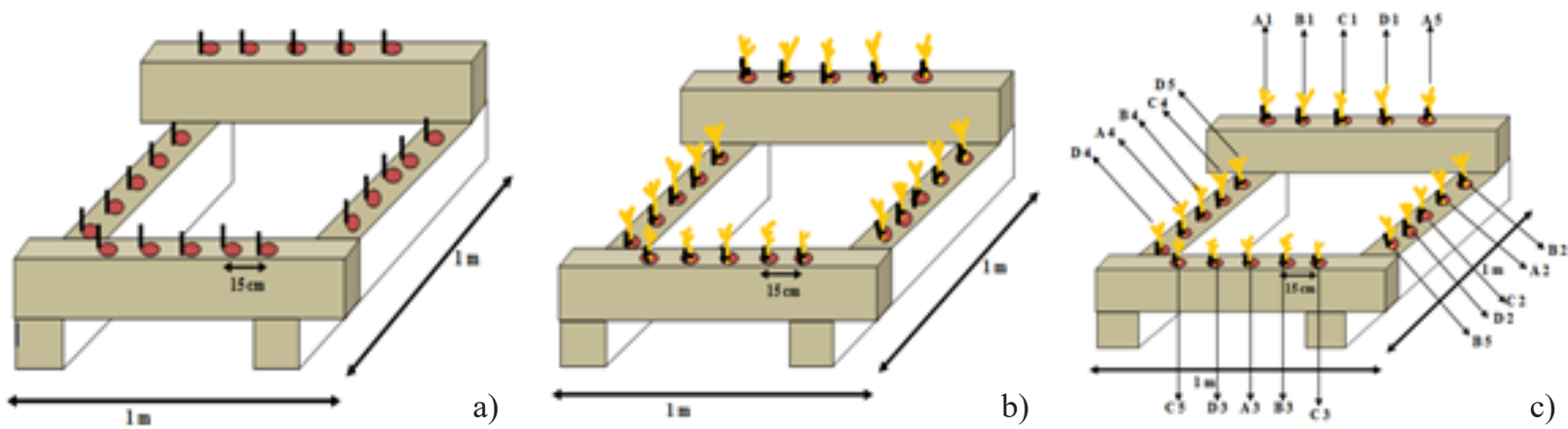

Gambar 2. Substrat tranplantasi karang (a); Desain peletakan karang transplantasi (b); dan

Letak perlakukan transpantasi karang (c).

Figure 2. Coral transplant substrate (a); Coral transplant design (b); and location of reef transportation treatment (c).

Optimasi Penggunaan Waktu Pembersihan untuk Suksesi Transplantasi Karang Acropora Millepora di Perairan Malang Rapat, Bintan - Bukhari, Risandi Dwirama Putra, \& Dedy Kurniawan 


\section{Kondisi Kualitas Perairan}

Kualitas perairan yang diukur dalam penelitian ini antara lain salinitas dengan menggunakan refraktometer, suhu menggunakan thermometer, oksigen terlarut menggunakan DO meter, $\mathrm{pH}$ menggunakan $\mathrm{pH}$ meter, kedalaman menggunakan patok skala, kecepatan arus menggunakan floating droudge, kekeruhan menggunakan turbidity meter dan laju sedimentasi menggunakan sediment traps.

\section{Analisis data}

Pertumbuhan mutlak berupa rata-rata ukuran fragmen karang yang ditransplantasikan selama 3 bulan, yang dihitung dengan menggunakan rumus (Ricker, 1975 dalam Lubis et al., 2016):

$\beta \mathrm{L}=\mathrm{L}_{\mathrm{t}}-\mathrm{L}_{0}$

Keterangan :

$\beta \mathrm{L}=$ Pertumbuhan mutlak tinggi karang $(\mathrm{mm})$,

$\mathrm{L}_{\mathrm{t}}=$ Rata-rata tinggi karang keras pada saat waktu ke-t, (mm),

$\mathrm{L}_{0}=$ Rata-rata tinggi karang keras pada saat waktu ke- $0,(\mathrm{~mm})$

Untuk menghitung laju pertumbuhan karang yang ditransplantasi selama waktu pengamatan, digunakan rumus (Ricker, 1975 dalam Lubis et al., 2016):

$$
P=\frac{(L t-L 0)}{(t)}
$$

Keterangan :

$\mathrm{P}=$ Laju pertumbahan tinggi karang $(\mathrm{mm} /$ minggu $)$,

$\mathrm{Lt}=$ Rata-rata tinggi fragmen karang setelah minggu ke-t (mm),

$\mathrm{L} 0=$ Rata-rata tinggi fragmen karang pada minggu ke-0 (mm), $\mathrm{t}=$ Waktu pengamatan (minggu)

Perhitungan tingkat kelangsungan hidup karang menggunakan rumus (Ricker, 1975 dalam Lubis et al., 2016):

$$
S R=\frac{N t}{N 0} \times 100 \%
$$

Keterangan:

$\mathrm{SR}=$ Tingkat kelangsungan hidup karang keras,

$\mathrm{N}_{\mathrm{t}}=$ Jumlah karang transplantasi pada waktu tertentu $\mathrm{N}_{0}=$ Jumlah karang transplantasi pada awal penelitian

Analisis perbedaan laju pertumbuhan antar perlakuan menggunakan analisis ragam satu arah (One Way ANOVA), jika terdapat perbedaan dilanjutkan dengan uji beda nyata menurut Post Hock Duncan dengan tingkat ketelitian $95 \%$. Proses analisis dilakukan dengan bantuan software SPSS 24.00.

\section{HASIL DAN PEMBAHASAN}

\section{Kondisi Kualitas Perairan}

Parameter yang diukur dalam penelitian ini meliputi; salinitas, suhu, oksigen terlarut (DO), derajat keasaman $(\mathrm{pH})$, kedalaman, kecepatan arus, kekeruhan dan laju sedimentasi. Hasil pengukuran parameter kualitas air di lokasi penelitian disajikan dalam Tabel 2.

Salinitas pada lokasi penelitian berkisar antara 3135 ppt dengan rata-rata 33,30 ppt. Mengacu pada baku mutu Peraturan Pemerintah Republik Indonesia Nomor 22 Tahun 2021 kondisi salinitas yang layak bagi pertumbuhan terumbu karang berkisar antara 3033 ppt. Dengan demikian, kondisi salinitas di lokasi penelitian tergolong sesuai dengan kehidupan terumbu karang. Suhu perairan tercatat memiliki kisaran yakni

Tabel 2. Kondisi kualitas perairan

\begin{tabular}{|c|c|c|c|c|}
\hline \multirow[t]{2}{*}{ Parameter } & \multirow[t]{2}{*}{ Satuan } & \multicolumn{2}{|c|}{ Hasil Pengukuran } & \multirow[t]{2}{*}{ Baku Mutu* } \\
\hline & & Kisaran & Rata-rata & \\
\hline Salinitas & ppt & $31-35$ & 33,30 & $33-34$ \\
\hline Suhu & ${ }^{\circ} \mathrm{C}$ & $28-32$ & 30,21 & $28-30$ \\
\hline Oksigen terlarut (DO) & $\mathrm{mg} / \mathrm{l}$ & $6,90-7,60$ & 7,25 & $>5$ \\
\hline Derajat keasaman $(\mathrm{pH})$ & - & $7,80-8,50$ & 8,27 & $7-8,50$ \\
\hline Kedalaman & $\mathrm{m}$ & $1-3,20$ & 2,41 & - \\
\hline Kecepatan arus & $\mathrm{m} / \mathrm{s}$ & $0,15-0,24$ & 0,20 & - \\
\hline Kekeruhan & NTU & $0,23-0,44$ & 0,37 & $<5$ \\
\hline Laju sedimentasi & $\mathrm{gr} / \mathrm{cm}^{2} /$ minggu & $0,00-23,98$ & 4,73 & - \\
\hline
\end{tabular}

Table 2. Condition of water quality

JURNAL KELAUTAN NASIONAL, Vol 16, No 2, Agustus 2021, Hal. 145-156 
antara $28-32^{\circ} \mathrm{C}$ dengan rata-rata $30,21^{\circ} \mathrm{C}$. Mengacu pada baku mutu Peraturan Pemerintah Republik Indonesia Nomor 22 Tahun 2021 kondisi suhu ini masih layak bagi pertumbuhan terumbu karang. Hal ini didukung oleh pendapat Nurman et al. (2017) yang mengemukakan bahwa terumbu karang memiliki kemampuan untuk mentolerir perubahan suhu sekitar $32-33^{\circ} \mathrm{C}$. Oksigen terlarut di lokasi penelitian berkisar antara 6,90-7,60 mg/l dengan rata-rata keseluruhan yakni 7,25 mg/1. Mengacu pada baku mutu Peraturan Pemerintah Republik Indonesia Nomor 22 Tahun 2021 kondisi oksigen terlarut yang layak bagi pertumbuhan terumbu karang yakni $>5 \mathrm{mg} / \mathrm{l}$. Derajat keasaman di lokasi penelitian tercatat berkisar antara 7,80-8,50 dengan rata-rata sebesar 8,27. Mengacu pada baku mutu Peraturan Pemerintah Republik Indonesia Nomor 22 Tahun 2021 kondisi derajat keasaman yang layak bagi pertumbuhan terumbu karang berkisar antara 7-8,50. Kedalaman perairan tercatat pada kiasaran 1-3,2 meter dengan rata-rata kedalaman sebesar 2,41 meter. Menurut Tioho et al. (2013) bahwa reef flat (rataan terumbu karang) hidup pada kedalaman saat surut terendah berkisar antara 1 sampai 1,50 meter, sedangkan pada saat pasang tertinggi kedalaman perairan berkisar antara 1,50 sampai 2 meter. Arus di lokasi penelitian berkisar antara 0,15-0,24 m/s dengan rata-rata kecepatan arus yakni $0,20 \mathrm{~m} / \mathrm{s}$. Menurut Johan et al. (2007), bahwa arus pada kegiatan budidaya karang hias rata-rata sebesar $0,087 \mathrm{~m} / \mathrm{s}$, kondisi arus ini tergolong baik untuk kehidupan terumbu karang. Sirkulasi air (arus) sangat penting dalam proses fisika karang, membantu proses fotosintesis dengan simbiosis dengan alga dan meningkatkan jaringan karang dalam pernapasan (Kurniawan et al., 2019).
Kekeruhan perairan diketahui berkisar antara 0,230,44 NTU dengan rata-rata 0,32 NTU tergolong baik bagi kehidupan terumbu karang, karena kekeruhan tergolong rendah. Mengacu pada baku mutu Peraturan Pemerintah Republik Indonesia Nomor 22 Tahun 2021 kondisi kekeruhan yang layak bagi pertumbuhan terumbu karang yakni $<5$ NTU. Laju sedimentasi yang dihitung berdasarkan hasil sedimen traps di lokasi penelitian tercatat berkisar antara 0-23,98 gr/ $\mathrm{cm}^{2} /$ minggu dengan rata-rata $4,73 \mathrm{gr} / \mathrm{cm} 2 / \mathrm{minggu}$. Penelitian Nurman et al. (2017), memperoleh hasil pengukuran sedimen terakumulasi berkisar antara 1-2,80 gr/cm2/hari atau 7-19,70 gr/cm2/minggu. Kisaran jumlah sedimen terakumulasi hampir sama dengan penelitian ini, meskipun akumulasi sedimen mengalami peningkatan, namun pertumbuhan panjang fragmen karang Acropora millepora masih tergolong tinggi, karena fragmen karang terus dilakukan pembersihan.

\section{Pertumbuhan Mingguan Karang Acropora millepora} Pertumbuhan karang Acropora millepora pada masingmasing perlakukan waktu pembersihan fragmen antara lain perlakuan A (fragmen dibersihkan setiap 1 minggu), perlakuan B (fragmen dibersihkan setiap 2 minggu), perlakuan $\mathrm{C}$ (fragmen dibersihkan setiap 3 minggu) dan perlakuan D (tidak ada pembersihan fragmen) memiliki pertambahan panjang yang berbedabeda. Proses perubahan pertumbuhan karang sebelum dan sesudah perlakukan disajikan Tabel 3. Hasil pengamatan pertumbuhan karang Acropora millepora selama waktu pengamatan disajikan pada Gambar 3.

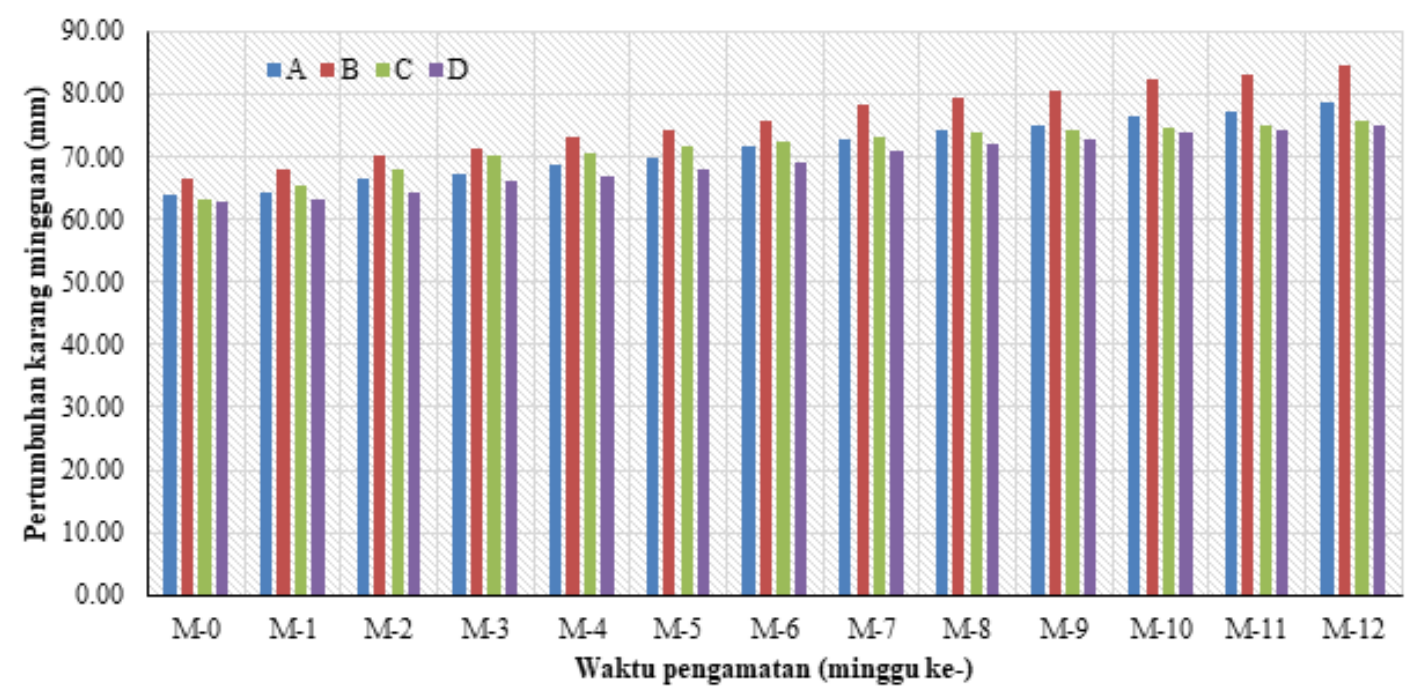

Gambar 3. Pertumbuhan mingguan fragmen karang Acropora millepora

Figure 3. Weekly growth of Acropora millepora coral fragments

Sumber: Hasil pengukuran

Optimasi Penggunaan Waktu Pembersihan untuk Suksesi Transplantasi Karang Acropora Millepora di Perairan Malang Rapat, Bintan - Bukhari, Risandi Dwirama Putra, \& Dedy Kurniawan 
Tabel 3. Perubahan pertumbuhan karang sebelum dan sesudah perlakukan Table 3. Changes in coral growth before and after treatment

\begin{tabular}{|c|c|c|}
\hline Fragmen Karang & Sebelum & Sesudah \\
\hline Fragmen Perlakuan & & \\
\hline
\end{tabular}
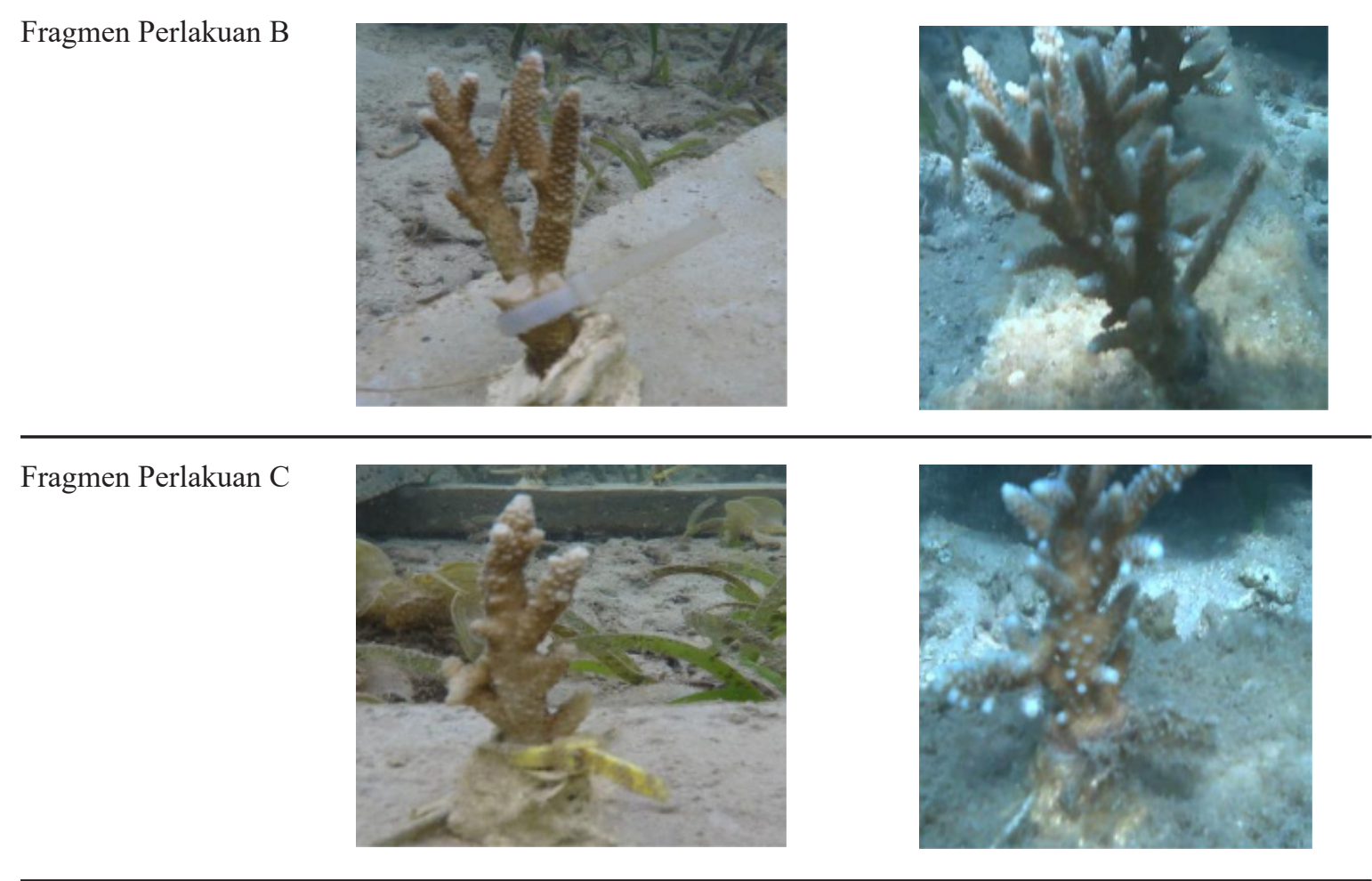

Fragmen Perlakuan D
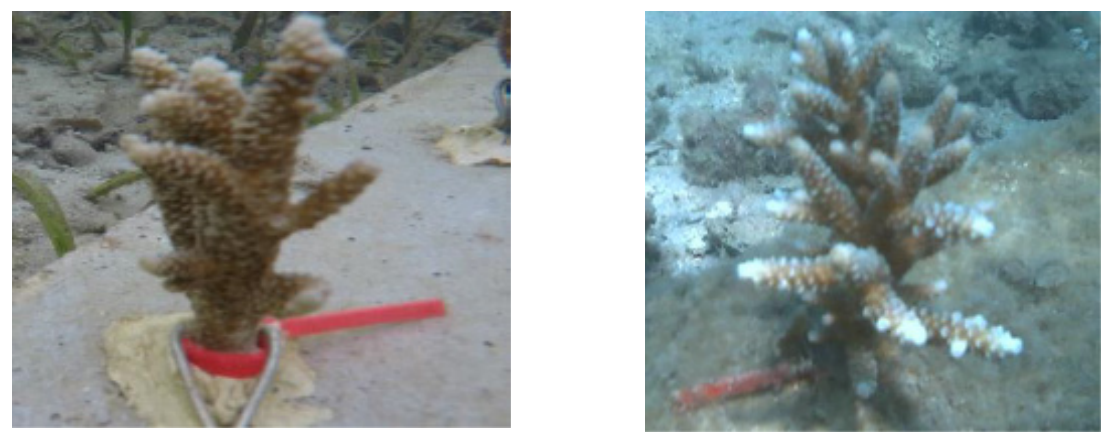
millepora dari minggu-0 sampai minggu terakhir (minggu ke 12), pada perlakuan A mengalami penambahan panjang dari 63,89 - 78,83 mm, pada perlakuan B mengalami penambahan panjang dari 66,40 - 84,56 mm, pada perlakuan C mengalami penambahan panjang dari 63,32 - 75,62 mm, dan pada perlakuan $\mathrm{D}$ mengalami penambahan panjang dari 62,75 - 74,97 mm selama 12 minggu. Penambahan panjang fragmen karang Acropora millepora pada perlakuan B merupakan yang tertinggi dibandingkan dengan perlakuan lainnya, sedangkan pertumbuhan fragmen karang Acropora millepora pada perlakuan D merupakan yang terendah. Pertumbuhan yang terendah pada fragmen dengan perlakuan D disebabkan karena polip karang akan tertutupi oleh adanya kotorankotoran atau partikel-partikel yang menyebabkan terjadinya hambatan pada proses fotosintesis alami yang dilakukan oleh zooxhantellae sehingga menghambat pertumbuhan karang. Menurut Rauf et al. (2015), cahaya matahari sangat penting bagi keberadaan zooxanthellae, cahaya digunakan oleh zooxanthellae untuk melakukan fotosintesis. Karena adanya simbiosis mutualisme antara zooxanthellae dan hewan karang maka proses fotosintesis ini sangat penting untuk kehidupan karang maupun hewan lain dan juga keberadaan zooxanthellae. Jika kondisi fragmen karang tertutupi oleh sampah maupun partikel lain, maka akan sangat mengganggu intensitas cahaya matahari yang akan diterima oleh fragmen karang.

\section{Pertumbuhan Mutlak Karang Acropora millepora}

Pertumbuhan mutlak karang yaitu rata-rata penambahan ukuran fragmen karang yang ditransplantasikan selama waktu pengamatan. Pertumbuhan mutlak dihitung dengan menggunakan rumus (Ricker, 1975) dengan bantuan Microsoft Excel 2016. Untuk melihat hasil pengukuran pertumbuhan mutlak (penambahan tinggi fragmen selama penelitian) disajikan pada Gambar 4.

Pertumbuhan panjang mutlak fragmen karang Acropora millepora menggambarkan nilai pertambahan panjang fragmen selama masa penelitian. Hasil pengamatan menunjukkan bahwa pertumbuhan mutlak pada perlakuan A sebesar 14,94 $\pm 4,98 \mathrm{~mm}$, perlakuan B mengalami pertumbuhan mutlak sebesar 18,16 \pm 5,93 mm, perlakuan $\mathrm{C}$ mengalami pertumbuhan mutlak sebesar 12,30 $\pm 3,78 \mathrm{~mm}$ dan perlakuan $\mathrm{D}$ mengalami pertumbuhan mutlak sebesar 12,22 \pm 4,34 mm. Dari hasil analisis tersebut, pertumbuhan mutlak tertinggi pada perlakuan B dan terendah pada perlakuan D.

Fragmen karang yang tidak dilakukan pembersihan akan mengakibatkan tertumpuknya oleh partikel sampah dan partikel sedimen yang menutupi polip karang. Faktor lain yang disebabkan oleh tidak adanya pembersihan fragmen, ialah terjadi pertumbuhan alga yang juga mempengaruhi perkembangan karang. Menurut penelitian Prasetyo et al. (2018), ketika tidak dibersihkannya fragmen karang dan substrat dari kotoran dan biota yang berasosiasi akan mempengaruhi nilai laju pertumbuhan mutlak ini disebabkan oleh tutupan alga pada fragmen karang yang tidak dibersihkan.

Pertumbuhan tertinggi pada perlakuan B yaitu pembersihan fragmen karang setiap 2 minggu 1 kali. Sehingga waktu pembersihan fragmen ini diduga baik untuk mendukung pertumbuhan karang transplantasi.

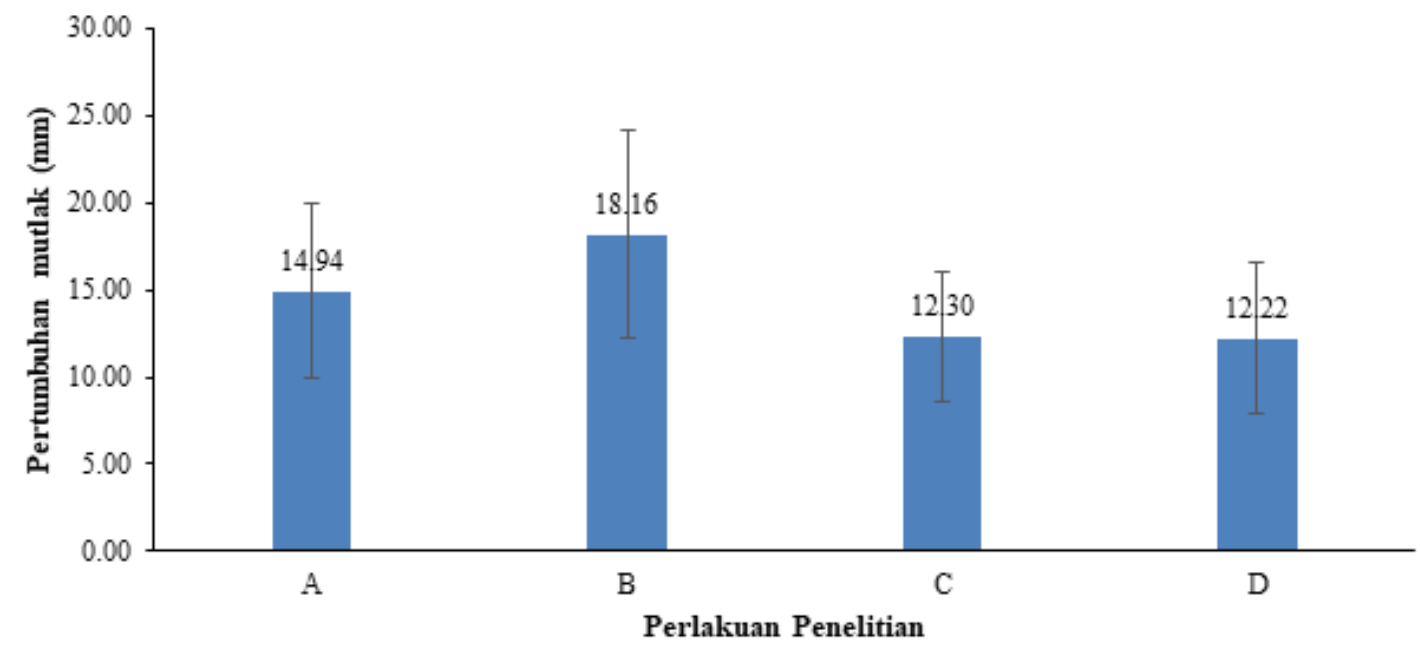

Gambar 4. Pertumbuhan mutlak fragmen karang Acropora millepora.

Figure 4. Absolute growth of Acropora millepora coral fragments.

Sumber: Hasil pengukuran

Optimasi Penggunaan Waktu Pembersihan untuk Suksesi Transplantasi Karang Acropora Millepora di Perairan Malang Rapat, Bintan - Bukhari, Risandi Dwirama Putra, \& Dedy Kurniawan 
Pembersihan yang terlalu sering dilakukan akan pula menimbulkan stress pada fragmen karang karena terpengaruh oleh adanya aktivitas pembersihan. Tingkat stress karang ditandai dengan keluarnya lendir pada fragmen disaat melakukan pembersihan yang rutin (setiap 1 minggu sekali). Kondisi ini dijelaskan oleh Nurman et al. (2017), pengeluaran lendir merupakan salah satu indikasi bahwa karang yang ditransplantasi dalam keadaan stress. Lendir yang dikeluarkan oleh karang merupakan bentuk adaptasi terhadap lingkungannya. Karang akan lama mengeluarkan lendir apabila berada pada kondisi lingkungan yang kurang mendukung untuk pertumbuhannya.

\section{Laju Pertumbuhan Karang Acropora millepora}

Laju pertumbuhan karang adalah pertumbuhan mutlak karang dibagi lamanya waktu pengamatan. Data laju pertumbuhan dianalisis dengan menggunakan rumus (Ricker, 1975) dengan bantuan Microsoft Excel 2016. Hasil analisis laju pertumbuhan fragmen karang Acropora millepora pada masing-masing perlakuan disajikan pada Gambar 5.

Hasil analisis laju pertumbuhan menunjukkan bahwa laju pertumbuhan fragmen karang pada perlakuan A sebesar 1,24 $\pm 0,41 \mathrm{~mm} /$ minggu atau 4,96 $\mathrm{mm} /$ bulan, laju pertumbuhan fragmen karang pada perlakuan B sebesar 1,51 $\pm 0,49 \mathrm{~mm} /$ minggu atau $6,05 \mathrm{~mm} /$ bulan, laju pertumbuhan fragmen karang pada perlakuan $\mathrm{C}$ sebesar $1,02 \pm 0,31 \mathrm{~mm} / \mathrm{minggu}$ atau $4,10 \mathrm{~mm} /$ bulan dan laju pertumbuhan fragmen karang pada perlakuan D sebesar 1,01 $\pm 0,36 \mathrm{~mm} /$ minggu atau $4,07 \mathrm{~mm} /$ bulan .
Laju pertumbuhan fragmen karang tertinggi terdapat pada perlakuan $\mathrm{B}$, sedangkan terendah pada perlakuan C. Hasil penelitian laju pertumbuhan fragmen karang Acropora millepora yang dilakukan oleh Johan et al. (2007), bahwa pertumbuhan karang hias jenis Acropora millepora berkisar antara 2,20-8,80 mm/bulan dengan rata-rata pertumbuhan karang Acropora millepora sebesar 5,80 mm/bulan. Pertumbuhan fragmen karang Acropora millepora di lokasi penelitian masih sesuai dengan kisaran pertumbuhan pada umumnya, kondisi ini disebabkan oleh intensitas cahaya yang baik dan kekeruhan yang rendah. Mengacu pada pernyataan Wijaya et al. (2017), tanpa cahaya yang cukup, laju fotosintesis akan berkurang dan bersama dengan itu kemampuan karang untuk menghasilkan kalsium karbonat dan membentuk terumbu akan berkurang. Jadi, kisaran penetrasi cahaya diatas masih termasuk normal dan dapat mendukung pertumbuhan terumbu karang.

\section{Kelangsungan Hidup Fragmen Karang Acropora millepora}

Fenomena yang dijumpai selama masa pemelihaan fragmen karang Acropora millepora pada lokasi transplantasi, beberapa fragmen karang mengalami pemutihan (bleaching) dan akan hitung sebagai jumlah fragmen yang mati. Kelangsungan hidup fragmen karang Acropora millepora di lokasi penelitian disajikan pada Gambar 6.

Tingkat kelangsungan hidup fragmen karang Acropora millepora pada perlakuan A dan perlakuan B sebesar

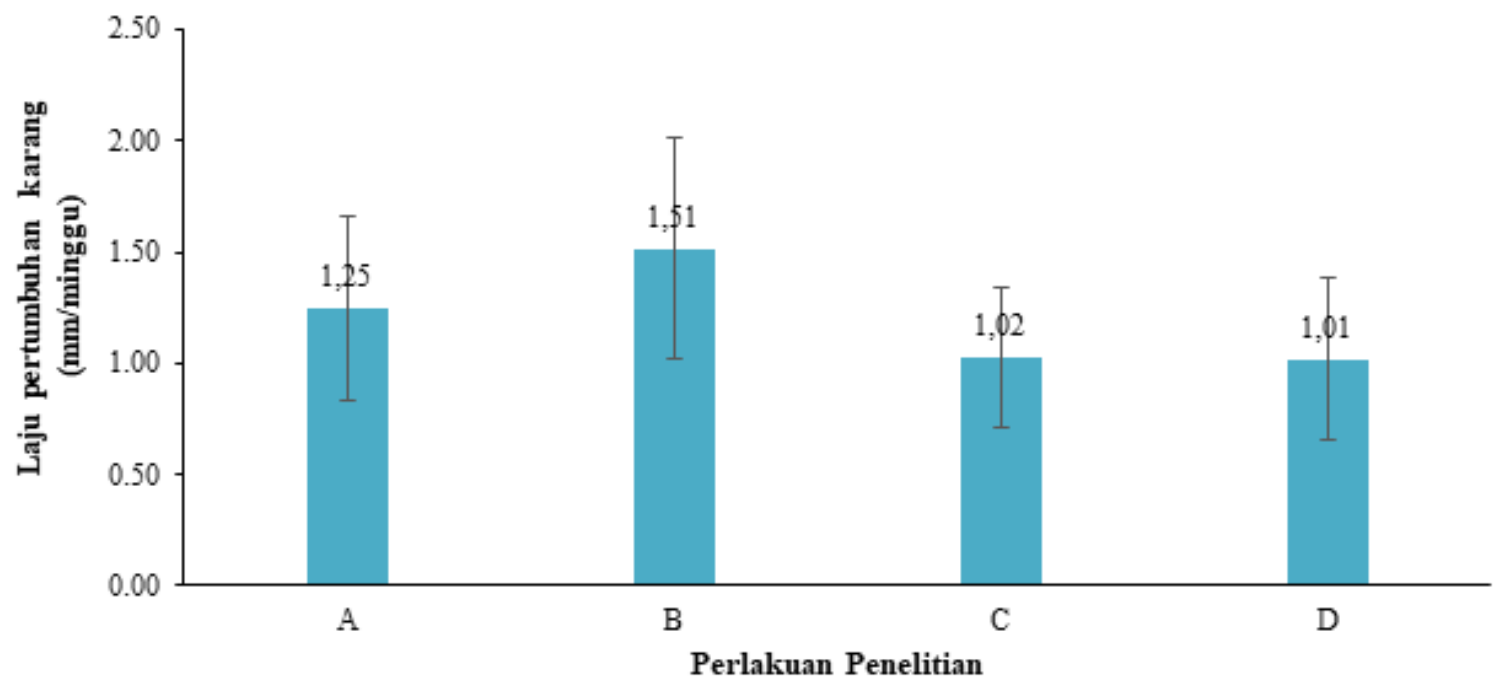

Gambar 5. Laju pertumbuhan fragmen karang Acropora millepora

Figure 5. Growth rates of Acropora millepora coral fragments Sumber: Hasil pengukuran 


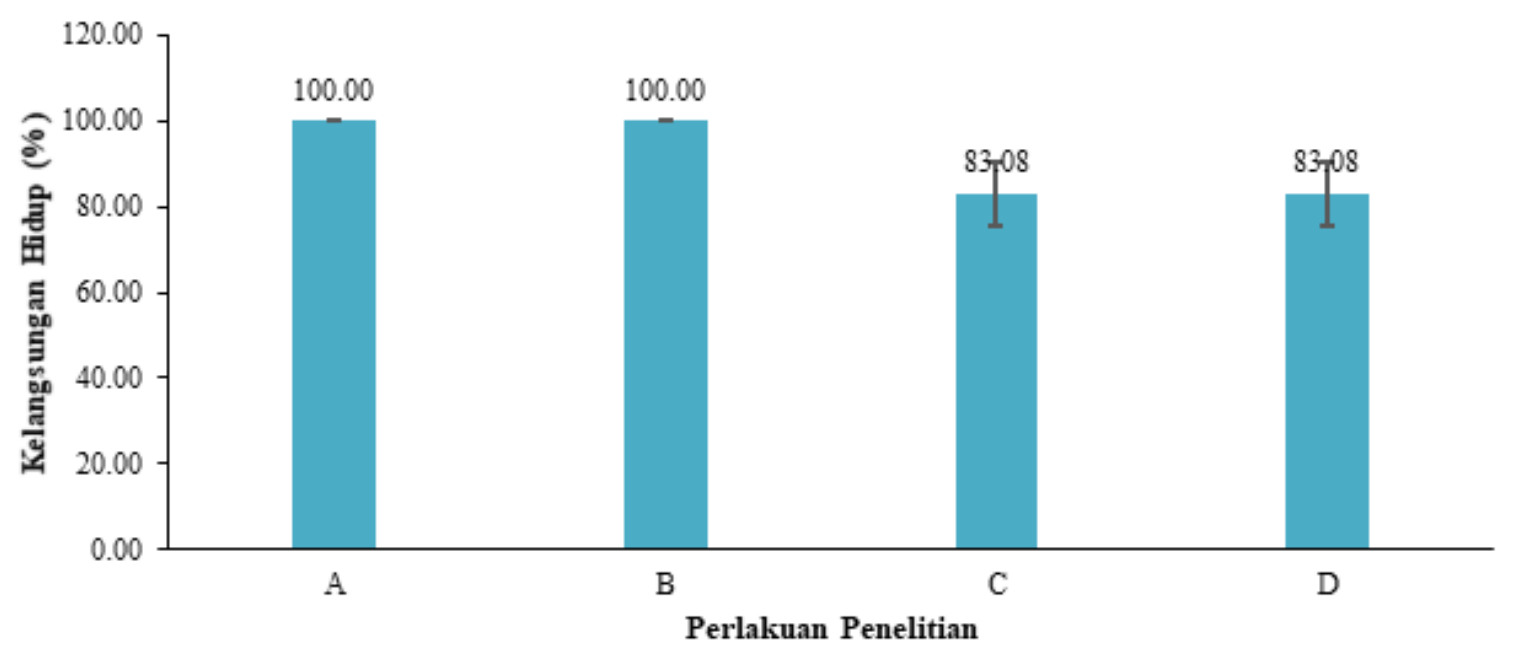

Gambar 6. Tingkat kelangsungan hidup fragmen karang Acropora millepora

Figure 6. Survival rates of Acropora millepora coral fragments

Sumber: Hasil pengukuran

$100 \% \pm 0,00 \%$. Tingkat kelangsungan hidup karang pada perlakuan C dan perlakuan D sebesar $83,08 \%$ $\pm 7,51 \%$ (mengalami kematian sebesar 6,92\%). Membandingkan hasil penelitian oleh Endo et al. (2006), yakni persentase kelangsungan hidup fragmen karang Acropora millepora di Pantai Kuta, Bali diperoleh rata-rata persentase kelangsungan hidup sebesar $68 \%$. Selanjutnya hasil penelitian Arifin \& Luthfi (2016), bahwa kelangsungan hidup karang Acropora sp. selama masa penelitian tergolong tinggi dengan nilai rata-rata sebesar $88,9 \%$ dan hanya mengalami kematian fragmen karang sebesar 11,1\%. Mengacu pada sumber-sumber penelitian tersebut, tingkat kelangsungan hidup fragmen karang di lokasi penelitian tergolong tinggi.

Fragmen karang Acropora millepora yang mengalami kematian pada perlakuan $\mathrm{C}$ dan $\mathrm{D}$ terjadi pada minggu ke-2 disebabkan oleh beberapa faktor diantaranya peningkatan jumlah partikel sedimen yang mengalami pengendapan (akumulasi sedimen) pada minggu ke-2. Pada periode minggu ke-2 dan minggu ke-3 akumulasi sedimen mencapai puncak yang tertinggi dibandingkan minggu-minggu lainnya masing-masing sebesar 19,18 $\mathrm{gr} / \mathrm{cm}^{2} / \mathrm{minggu}$ dan $23,98 \mathrm{gr} / \mathrm{cm}^{2} / \mathrm{minggu}$. Kondisi ini menjadi salah satu faktor yang menyebabkan adanya kematian fragmen pada masa periode minggu ke-2. Partikel sedimen yang mengalami akumulasi terendapkan kedasar perairan dan menutupi polip karang kemudian mempengaruhi tingkat konsumsi cahaya yang dibutuhkan oleh fragmen karang tersebut. Dalam kondisi tertentu, fragmen karang yang tertutupi oleh partikel sedimen mengalami kerentanan akan mengalami proses pemutihan bleaching dan tidak bertumbuh kembang (mati). Menurut Prasetyo et al. (2018), pengaruh sedimentasi terhadap terumbu karang yaitu apabila laju sedimentasi tinggi maka tutupan terumbu karang akan semakin rendah. Tidak hanya mampu mempengaruhi laju pertumbuhan karang, sedimentasi juga mampu mempengaruhi morfologi dari koloni karang.

\section{Analisis Pengaruh Frekuensi Waktu Pembersihan Terhadap Laju Pertumbuhan Karang Acropora millepora}

Hasil analisis uji beda nyata pengaruh frekuensi waktu pembersihan terhadap laju pertumbuhan karang Acropora millepora di Perairan Malang Rapat disajikan secara lengkap dalam Tabel 4.

Berdasarkan hasil analisis beda nyata diketahui bahwa nilai $\mathrm{F}_{\text {hitung }} 2,843>\mathrm{F}_{\text {tabe }} 10,309$ maka hasil analisis diterima. Kondisi ini mencirikan bahwa ada perbedaan yang nyata laju pertumbuhan fragmen karang Acropora millepora pada masing-masing perlakuan. Untuk menguji perbedaan laju pertumbuhan fragmen karang Acropora millepora dilakukan uji lanjut Duncan untuk memastikan kesimpulan analisis beda nyata yang telah dianalisis sebelumnya. Berdasarkan hasil uji lanjut Duncan disajikan secara rinci dalam Tabel 5.

Berdasarkan uji lanjut Duncan terdapat perbedaan yang nyata dari laju pertumbuhan fragmen karang Acropora millepora. Dari hasil uji tersebut, terdapat 2 kelompok laju pertumbuhan fragmen karang Acropora millepora yakni pada kelompok pertama (perlakuan D, C, A) 
Tabel 4. Hasil uji beda nyata pertumbuhan fragmen karang Acropora millepora Table 4. Results of significant differences growth of Acropora millepora coral fragments

\begin{tabular}{llllll}
\hline Variabel & $\begin{array}{l}\text { Sum of } \\
\text { Squares }\end{array}$ & df & Mean Square & F & Sig. \\
\hline Perlakuan & 1.752 & 3 & .584 & 2.843 & .071 \\
Pertumbuhan & 3.285 & 16 & .205 & & \\
Total & 5.037 & 19 & & & \\
\hline
\end{tabular}

Sumber: Hasil perhitungan

Tabel 5. Hasil uji lanjut Duncan pertumbuhan fragmen karang Acropora millepora Table 5. Duncan's further test results of growth of Acropora millepora coral fragments

\begin{tabular}{cllll}
\hline \multirow{2}{*}{ Perlakuan } & N & \multicolumn{2}{c}{ Subset for alpha $=\mathbf{0 . 0 5}$} \\
\cline { 3 - 4 } Duncana & & & $\mathbf{1}$ \\
& D & 5 & .7720 & \\
C & 5 & .8800 & .8800 \\
A & 5 & 1.2460 & 1.2460 \\
B & 5 & & 1.5160 \\
Sig. & .136 & .050 & \\
\hline Sumber: Hasil perhitungan & & &
\end{tabular}

dengan nilai signifikan sebesar 0,136 dan kelompok kedua (perlakuan $\mathrm{C}, \mathrm{A}, \mathrm{B}$ ) dengan nilai signifikan sebesar 0,050. Dari kedua kelompok tersebut, dapat disimpulkan bahwa laju pertumbuhan fragmen karang Acropora millepora memiliki berbeda yang signifikan antar masing-masing perlakuan terutama pada perlakuan B dengan D. Dari uji lanjut tersebut, terlihat jelas bahwa perlakuan D (tidak ada pembersihan fragmen) memiliki pertumbuhan yang paling rendah, sedangkan perlakuan B (fragmen dibersihkan setiap 2 minggu) merupakan perlakuan dengan nilai optimal (pertumbuhan tertinggi) dibandingkan perlakuan lainnya.

Hal ini dikarena pada perlakuan B (fragmen dibersihkan setiap 2 minggu) laju pertumbuhan tertinggi dikarenakan adanya pembersihan terhadap sedimen dan alga yang melekat. Pembersihan setiap 2 minggu merupakan pertumbuhan yang paling optimum diduga karena, kurangnya sentuhan secara langsung dari aktivitas pembersihan fragmen sehingga dapat mengurangi stress pada fragmen karang. Menyentuh terumbu karang dapat mengakibatkan melukai terhadap terumbu karang itu sendiri sehingga mengeluarkan lendir dan mengalami stress. Pendapat ini didukung penelitian yang dilakukan oleh Prameliasari et al. (2012), pengeluaran lendir (mucus) akibat proses aktivitas pembersihan yang melukai karang diduga merupakan tanda bahwa karang mengalami stress. Selain itu juga, waktu pembersihan setiap 2 minggu diduga efektif dalam pembersihan sedimen dan alga yang melekat pada substrat tempat melekatnya fragmen karang. Anggara et al. (2017) menyatakan bahwa adanya sedimentasi yang tinggi di ekosistem terumbu karang dapat mempercepat pertumbuhan alga. Lebih lanjut menurut Edwards \& Gomez (2008), jika algaalga dibiarkan tumbuh di sekitar substrat transplan, maka akan mengganggu pertumbuhan karang transplan dan proses pelekatan karang transplan ke substrat.

\section{KESIMPULAN DAN SARAN}

1. Pertumbuhan mutlak pada perlakuan A sebesar 14,94 $\pm 4,98 \mathrm{~mm}$, perlakuan B sebesar 18,16 $\pm 5,93 \mathrm{~mm}$, perlakuan $\mathrm{C}$ sebesar $12,30 \pm 3,78 \mathrm{~mm}$ dan perlakuan D sebesar 12,22 $\pm 4,34 \mathrm{~mm}$.

2. Laju pertumbuhan fragmen karang pada perlakuan $A$ sebesar 1,24 $\pm 0,41 \mathrm{~mm} /$ minggu, perlakuan B sebesar $1,51 \pm 0,49 \mathrm{~mm} / \mathrm{minggu}$, perlakuan $\mathrm{C}$ sebesar $1,02 \pm$ $0,31 \mathrm{~mm} / \mathrm{minggu}$, dan laju perlakuan D sebesar 1,01 $\pm 0,36 \mathrm{~mm} /$ minggu.

3. Tingkat kelangsungan hidup fragmen karang Acropora millepora pada perlakuan A dan B sebesar $100 \%$ (tidak mengalami kematian), sedangkan perlakuan C dan D sebesar 83,08\% (mengalami kematian).

4. Terdapat perbedaan yang nyata antara pengaruh waktu pembersihan terhadap laju pertumbuhan karang Acropora millepora. Perlakuan B merupakan perlakuan dengan nilai laju pertumbuhan optimal (pertumbuhan tertinggi) dibandingkan perlakuan lainnya. 
Dari hasil penelitian disarankan untuk melakukan kegiatan transplantasi fragmen karang Acropora millepora sebaiknya dilakukan pembersihan setiap 2 minggu sekali. Dikarenakan waktu ini diduga efektif untuk membersihkan sedimen dan alga yang melekat pada substrat transplan.

\section{UCAPAN TERIMA KASIH}

Ucapan terima kasih penulis ucapkan ke semua pihak yang telah membantu terlaksananya seluruh kegiatan penelitian sampai selesai.

\section{DAFTAR PUSTAKA}

Haris, A., Andy Omar, S. B., \& Kurniawan, D. (2011). Studi pertumbuhan dan tingkat kelangsungan hidup karang Goniopora stokesii (Blainville, 1830) menggunakan teknologi biorock. Prosiding Seminar Nasional Perikanan dan Kelautan "Bringing the Better Science for Better Fisheries and the Better Future", 1119. Pekanbaru: Fakultas Perikanan dan Ilmu Kelautan, Universitas Riau.

Subhan, B., Madduppa, H., Arafat, D., \& Soedharma, D. (2014). Bisakah transplantasi karang perbaiki ekosistem terumbu karang. Risalah Kebijakan Pertanian dan Lingkungan, 1(3), 159-164.

Kurniawan, D., Jompa, J., \& Haris, A. (2017). Pertumbuhan tahunan karang Goniopora stokesi di Perairan Kota Makassar hubungannya dengan faktor cuaca. Jurnal Akuatiklestari, 1(1), 7-14.

Edwards, A. J. \& Gomez, E. D. (2008). Konsep dan panduan restorasi terumbu: membuat pilihan bijak di antara ketidakpastian. Terj. dari Reef Restoration Concepts and Guidelines: making sensible management choices in the face of uncertainty. Oleh: Yusri, S., Estradivari, N. S. Wijoyo, \& Idris. Yayasan TERANGI, Jakarta: iv $+38 \mathrm{hlm}$.

Putra, R. D., Suryanti, A., Kurniawan, D., Pratomo, A., Irawan, H., Raja, T. S., Kurniawan, R., Pratama, G.,\& Jumsu, J. (2018). Responses of herbivorous fishes on coral reef cover in Outer Island Indonesia (Study Case: Natuna Island). Prosiding SCiFiMaS. E3S Web of Conferences, 47, 04009. Purwokerto: Universitas Jenderal Soedirman.
Dean, A., \& Kleine, D. (2011). Terumbu karang dan perubahan iklim. Brisbane, Australia: University of Queensland.

Irawan. H., Yude. R., Suhana. M.P., Suryanti. A., Kurniawan. D., Zahra. A., Putra, R., Razai, T., Yunianto, A., Syakti, A. (2019). Assembled concrete reefs as a stand for coral transplantation on the seabed. IOP Conference Series: Earth and Environmental Science, 348(1). 012046. DOI:10.1088/1755-1315/348/1/012046

Lubis, S.B., Suraji, Mudatstsir, Sari, R.P., Miasto, Y., Prabowo, et al. (2016). Pedoman Rehabilitasi bambu laut (Isis hippuris) dengan metode transplantasi. Jakarta: Direktorat Konservasi dan Keanekaragaman Hayati Laut Ditjen Pengelolaan Ruang Laut Kementerian Kelautan dan Perikanan.

Peraturan Pemerintah Republik Indonesia Nomor 22 Tahun 2021 tentang Penyelenggaraan Perlindungan dan Pengelolaan Lingkungan Hidup, Lampiran VIII. Baku Mutu Air Laut.

Nurman, F. H., Sadarun, B., \& Palupi, R. D. (2017). Survival rate of coral Acropora formosa as transplantation results in Sawapudo Waters Soropia District. Sapa Laut, 2(4), 119-125.

Tioho, H., Paruntu, C. P., \& Patrich, H. (2013). Ketahanan hidup dan laju pertumbuhan karang Scleractinia yang di transplantasi pada rataan terumbu Perairan Kalasei, Kabupaten Minahasa, Sulawesi Utara. Aquatic Science and Management, 1(2), 111-116.

Johan, O., Sugama, K., \& Insan, I. (2007). Propagasi karang di Indonesia. Jakarta: Pusat Riset Perikanan Budidaya.

Kurniawan, D., Febrianto, F., \& Hasnarika. (2019). Kondisi ekosistem terumbu karang di Perairan Teluk Sebong Kabupaten Bintan. Jurnal Pengelolaan Perairan, 2(2), 13-26.

Rauf, K. P., Supriyono., \& Purnomo P. W. (2015). Abundance of zooxanthellae in Acropora sp. based on depth and difference of shading in Pari Island, Seribu Islands Jakarta. Diponegoro Journal of Maquares, 4(1), 46-54. 
Prasetyo, A. B. T., Yuliadi, L. P., Astuty, S., \& Prihadi, D. J. (2018). Keterkaitan tipe substrat dan laju sedimentasi dengan kondisi tutupan terumbu karang di Perairan Pulau Panggang, Taman Nasional Kepulauan Seribu. Jurnal Perikanan dan Kelautan, 9(2), 1-7.

Wijaya, C. K., Komala, R., \& Giyanto. (2017). Condition, diversity, and growth forms of coral in Kayu Angin Genteng Island, Seribu Islands. Bioma, 13(2), 108-110.

Endo, S., Prasetyo, R., Nishihira, M., \& Onaka, S. (2006). Experimental coral transplantation in the moat of Kuta beach, Bali Island, Indonesia. PROCEEDINGS OF COASTAL ENGINEERING JSCE, Ocean Exposition Commemorative Park, Management Foundation and Meio University. 55. DOI:10.2208/proce1989.55.1121

Arifin, Z., \& Luthfi, O. M. (2016). Studi pertumbuhan dan survival rate pada transplantasi karang Acropora sp. di Pantai Kondang Merak, Kabupaten Malang. Prosiding Seminar Nasional Perikanan dan Kelautan VI, 5, 556-561. Malang: Fakultas Perikanan dan Ilmu Kelautan, Universitas Brawijaya.

Prameliasari, T. A., Munasik., \& Wijayanti, D. P. (2012). Pengaruh perbedaan ukuran fragmen dan metode transplantasi terhadap pertumbuhan karang Pocillopora damicornis di Teluk Awur, Jepara. Journal Of Marine Research, 1(1), 159168.

Anggara, S. P., Tanjung, A., \& Eizal. (2017). Kondisi Terumbu Karang di Sekitar Perairan Banyan Tree Bintan Kabupaten Bintan Provinsi Kepulauan Riau. Repository UNRI. 